\title{
A facile nano-iron oxide sensor for the electrochemical detection of the anti- diabetic drug linagliptin in the presence of glucose and metformin
}

\author{
Manal A. El-Shal, Shereen M. Azab and Hassan A. M. Hendawy
}

\begin{abstract}
Background: A highly sensitive sensor for the electrochemical determination of an antidiabetic drug Linagliptin (LG) was constructed using carbon paste electrode (CPE) modified with iron oxide nanoparticles $\left(\mathrm{Fe}_{2} \mathrm{O}_{3} \mathrm{NPs}\right)$. The electrochemical performance of LG was examined analytically, and some dynamics were considered for the first time.

Results: This work indicates that the oxidation reaction of $\mathrm{LG}$ on $\mathrm{CPE} / \mathrm{Fe}_{2} \mathrm{O}_{3} \mathrm{NPs}$ is a one electron and one proton process, which is controlled by both diffusion and adsorption. The simultaneous determination of LG with glucose and metformin (MET) was also considered by square wave voltammetry in universal buffer pH 7.4. Experimental results specify a linear relation between LG peak current and its concentration in the range of 0.03 to $86 \mu \mathrm{g} / \mathrm{ml}$, leading to a detection limit of $8.0 \mathrm{ng} / \mathrm{ml}$.
\end{abstract}

Conclusion: This novel sensor was successfully used to determine LG in commercialized tablets and in spiked urine samples.

Keywords: Diabetes, Iron oxide nanoparticles, Linagliptin, Carbon paste electrode

\section{Background}

Finding new methods for the problems in the medical field is the center of researchers everywhere. Diabetes mellitus is a worldwide public health problem. People who have diabetes can develop serious or life-threatening complications, so taking medication(s) may help to manage diabetes and improve health (Association AD 2014). Insulin deficiency and hyperglycemia cause the concentration of blood glucose to increase or decrease than the normal range of $80-120 \mathrm{mg} / \mathrm{dL}$ (4.4-6.6 mM), which leads to death (Waldhäusl et al. 1979). The complications of fighting diabetes, include heart disease, kidney failure, or blindness, which can be reduced through personal control of blood glucose (Group UPDS 1998). Linagliptin is a dipeptidyl peptidase-4 (DPP-4) inhibitor

\footnotetext{
* Correspondence: dr-manalelshal@hotmail.com

Pharmaceutical Chemistry Department, National Organization for Drug Control and Research [NODCAR], 6 Abu Hazem Street, Pyramids Ave, P.O. Box 29, Giza, Egypt
}

\section{Springer Open}

(c) The Author(s). 2019 Open Access This article is distributed under the terms of the Creative Commons Attribution 4.0 International License (http://creativecommons.org/licenses/by/4.0/), which permits unrestricted use, distribution, and reproduction in any medium, provided you give appropriate credit to the original author(s) and the source, provide a link to the Creative Commons license, and indicate if changes were made.
II diabetes in patients who cannot control blood suy of in alone. Linagliptin wor of insulin released and decreasing the amount of sugar made by the body by slowing the breakdown of insulinotropic hormone glucagon-like peptide (GLP)-1 for better glycemic control.

Combination therapy has a pivotal role in type II diabetes mellitus management in patients unable to maintain normal glycemic level using metformin alone. Addition of linagliptin, dipeptidyl peptidase-IV inhibitor, to metformin improves glycemic control. Various analytical techniques are applied for simultaneous determination of binary diabetes drugs mixture such as LG and MET mixture (Haak 2015) including HPLC with UV detector (Vemula et al. 2015), LC-MS/MS (Abbas Moussa et al. 2019), and UV-Vis diffuse reflectance spectroscopy (El-Bagary et al. 2013). No electrochemical 
reported work applied for the determination of either the LG or our studied mixture, only voltammetric determination for MET (Brocks et al. 2010).

Magnetic nanoparticles (NPs) are in the focus of much interest especially iron oxide nanoparticles due to their enormous and unique physical and chemical properties. The most considered materials with promising properties are those with magnetic properties due to their enormous and unique physical and chemical properties and applications such as drug delivery, biomedical uses, and tumor labeling (Jalilian et al. 2009; Polyak and Friedman 2009) . These applications require that the nanoparticles have high magnetization values, a size smaller than $100 \mathrm{~nm}$, and a narrow particle size distribution. The nano-size of iron oxide nanoparticles and its biocompatibility make them perfect for surface engineering and functionalization (Laurent et al. 2011; Prodan et al. 2013). Also, $\mathrm{Fe}_{2} \mathrm{O}_{3}$ NPs provide a path to a new generation of chemical and electrochemical sensors for glucose biosensor applications with some materials such as Pt nanoparticles and multi-walled carbon nanotubes ( $\mathrm{Li}$ et al. 2010; Rong et al. 2007), Ni oxide nanoparticles (Salimi et al. 2007), and silicon dioxide (Baby and Ramaprabhu 2010). The goal of the present work is to carry out a study on the effect of different parameters such as $\mathrm{pH}$, scan rate, and the effect of changing the percentage of $\mathrm{Fe}_{2} \mathrm{O}_{3} \mathrm{Nps}$ added, on the determination of LG raw material, on pharmaceutical formulation, and in human urine samples.

\section{Experimental}

\section{Materials}

Linagliptin (LG) was supplied from the European Egyptian Pharmaceutical Industries, Egypt, iron nanoparticles. Graphite powder and paraffin oil were purchased from sigma Aldrich. Universal buffer ( $\mathrm{B}-\mathrm{R}$ buffer) 0.04 $\mathrm{M}$ of $\mathrm{pH} 2-11\left(\mathrm{CH}_{3} \mathrm{COOH}+\mathrm{H}_{3} \mathrm{BO}_{3}+\mathrm{H}_{3} \mathrm{PO}_{4}\right)$, was used as the supporting electrolyte, then $0.2 \mathrm{M} \mathrm{NaOH}$ was used to gain the desired $\mathrm{pH}$ value.

\section{Apparatus}

All voltammetric measurements were performed by stationary electrode using 797VA Computrace software (1.0) from Metrohm, Switzerland, electrochemical analyzer. A three-electrode cell system incorporating the carbon paste electrode as a working electrode and the impedance measurements were done by the threeelectrode electrochemical workstation EC-Lab SP-150 potentiostat. A platinum wire as an auxiliary electrode was used with respect to calomel reference electrode. Energy-dispersive X-ray measurements were performed by EDX spectroscopy unit of Model Quanta 250 FEG (Field Emission Gun) with accelerating voltage $30 \mathrm{KV}$.

\section{Methods}

\section{Preparation of $\mathrm{CPE} / \mathrm{Fe}_{2} \mathrm{O}_{3} \mathrm{NP}$ sensor}

Carbon paste electrode (CPE) was prepared by mixing graphite powder $(0.5 \mathrm{~g})$ with drops of nujol oil in a glass mortar. $\mathrm{CPE} / \mathrm{Fe}_{2} \mathrm{O}_{3} \mathrm{NP}$-modified electrode was prepared by mixing ratios of $5,10,12,15$, and $20 \%$ modified paste containing $95,90,88,85$, and $80 \mathrm{mg}$ of graphite powder and $5,10,12,15$, and $20 \mathrm{mg}$ of $\mathrm{Fe}_{2} \mathrm{O}_{3} \mathrm{NP}$ modifier mixed, respectively, with suitable amount of paraffin oil. The components were stirred for $10 \mathrm{~min}$ in a glass mortar at room temperature to achieve homogenous paste that was used for voltammetric measurements without preconditioning.

\section{Validation in pharmaceutical samples}

Five tablets of the commercial pharmaceutical Trajenta (5 mg LG/Tablet) were powdered and dissolved in deionized water. After supersonic treatment for $30 \mathrm{~min}$, it was filtered and the concentration of LG in the working range was achieved, and then, SWV were recorded using the standard addition method.

\section{Analysis of spiked urine samples}

Urine was supplied from healthy volunteers; the spiked urine sample was centrifuged for $10 \mathrm{~min}$ at $13,000 \mathrm{rpm}$ to get rid of protein residues, and then, the supernatant was taken carefully. An aliquot $(1 \mathrm{~mL})$ of the clear solution was added to a mixture of $9 \mathrm{~mL} B-\mathrm{R}$ buffer to achieve a final concentration of $1.0 \mathrm{mM}$, at an optimum $\mathrm{pH}$ value to perform a calibration curve.

\section{Result}

\section{Surface characterization}

Figure 1 shows SEM images of the bare CPE and CPE/ $\mathrm{Fe}_{2} \mathrm{O}_{3} \mathrm{NP}$-fabricated electrodes. The surface of the CPE is dominated with microstructure with a heterogeneous grain growth, (Fig. 1a). In Fig. 1b, $\mathrm{CPE} / \mathrm{Fe}_{2} \mathrm{O}_{3} \mathrm{NP}$ surface (Shehata et al. 2016) showed small iron oxide nanoparticles placed at different sites over the CPE surface with a cloudy aggregates and uniform distribution, displaying a larger surface area.

Electrochemical impedance spectroscopy scans were measured at peak potential $(1050 \mathrm{mV})$ for bare CPE, and CPE modified with $10 \%, 12 \%, 15 \%$, and $20 \% \mathrm{Fe}_{2} \mathrm{O}_{3} \mathrm{NPs}$ are shown in (Fig. 2) as Nyquist plots. It shows a semicircle at high frequency indicating a charge transfer process connected to a linear line at low frequency indicating a diffusion process (Azab and Fekry 2017a, 2017b). Thus, the mechanism of the reaction depends on both charge transfer and diffusion processes. The diameter of the semicircle increases in the following order: bare CPE $>10 \% \mathrm{Fe}_{2} \mathrm{O}_{3} \mathrm{NPs}>12 \% \mathrm{Fe}_{2} \mathrm{O}_{3} \mathrm{NPs}>20 \%$ $\mathrm{Fe}_{2} \mathrm{O}_{3} \mathrm{NPs}>15 \% \mathrm{Fe}_{2} \mathrm{O}_{3} \mathrm{NPs}$. The Nyquist plot data were simulated with equivalent circuit (inset) with $2 \%$ error. 


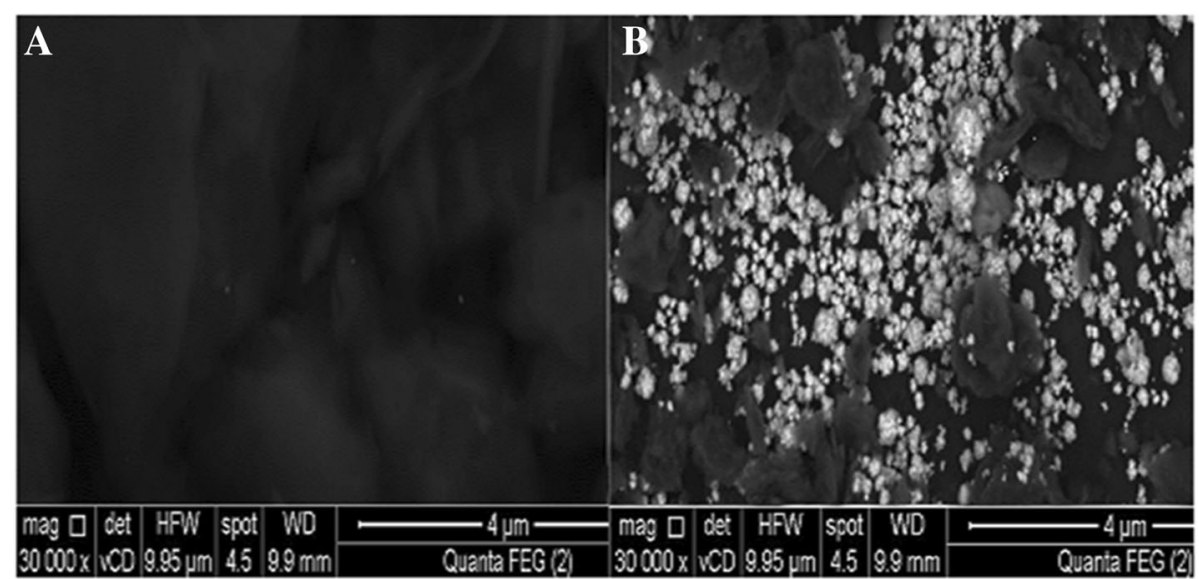

Fig. 1 The SEM image of $\mathbf{a}$ bare $\mathrm{CPE}$ and $\mathbf{b} \mathrm{CPE} / \mathrm{Fe}_{2} \mathrm{O}_{3} \mathrm{NPS}$

Analysis was performed by Thales software provided with the Zahner-Electric workstation (Polyak and Friedman 2009). The model consists of $R_{4} Z_{\mathrm{w}} C_{3}, R_{3} C_{2}$, and $R_{2} C_{1}$ in series with the solution resistance $\left(R_{1}\right)$. C refers to the capacitance; $R$ is the resistance, and $Z_{\mathrm{w}}$ is the Warburg component related to diffusion (Bard et al. 1980). Generally, the data shows that upon the addition of $15 \% \mathrm{Fe}_{2} \mathrm{O}_{3} \mathrm{NPs}$ the oxidation of LG gives lower impedance value (highest conductivity) and highest diffusion process $\left(W=41.7 \Omega \mathrm{cm}^{2} \mathrm{~s}^{-1 / 2}\right)$ compared to $W=$ $37.1 \Omega \mathrm{cm}^{2} \mathrm{~s}^{-1 / 2}$ for the bare CPE, due to large surface area (Azab and Fekry 2017a, 2017b; Mohamed et al. 2017) that NPs provide giving a nano-environment with

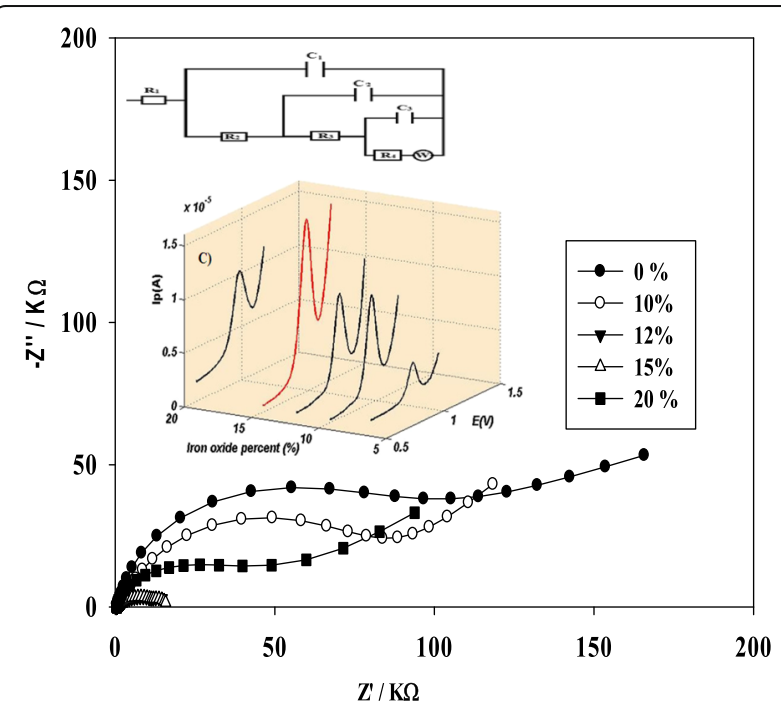

Fig. 2 Nyquist plots for $L G$ using bare CPE and CPE/ $\mathrm{Fe}_{2} \mathrm{O}_{3} \mathrm{NPs}$ with different concentration of $\mathrm{Fe}_{2} \mathrm{O}_{3} \mathrm{NPs}$. Inset 1: Equivalent circuit. Inset 2: Electrochemical oxidation responses of $L G$ using different concentrations of $\mathrm{Fe}_{2} \mathrm{O}_{3} \mathrm{NPS}$ high electron communication features for the electrochemical detection of LG with fast and good capacity which progress the direct electron movement between the active sites of NPs and LG. The same result was obtained in the SWV of $1.0 \mathrm{mM}$ LG (inset), in which it was clear that the highest anodic peak current was achieved when $15 \% \mathrm{Fe}_{2} \mathrm{O}_{3} \mathrm{NPs}$ was used.

The cyclic voltammograms of hexacyanoferrate (II) (Fig. 3) showed well-defined redox peaks for the modified $\mathrm{CPE} / \mathrm{Fe}_{2} \mathrm{O}_{3} \mathrm{NPs}$, with mid-point potential at ca. $+0.450 \mathrm{~V}$ vs $\mathrm{Ag} / \mathrm{AgCl}$ (slightly higher than for the bare CPE at ca. $+0.400 \mathrm{~V}$ ). The shapes of the CVs were almost unaffected by the scan rate, and both cathodic and anodic peak currents depend linearly on the square root of the scan rate over the entire range of scan rates considered, indicating a diffusion-controlled electrochemical process, with no adsorption on the $\mathrm{Fe}_{2} \mathrm{O}_{3} \mathrm{NP}$. When $\mathrm{Fe}_{2} \mathrm{O}_{3} \mathrm{NP}$ is cobimbined to the graphite paste, larger differences between oxidation and reduction peaks

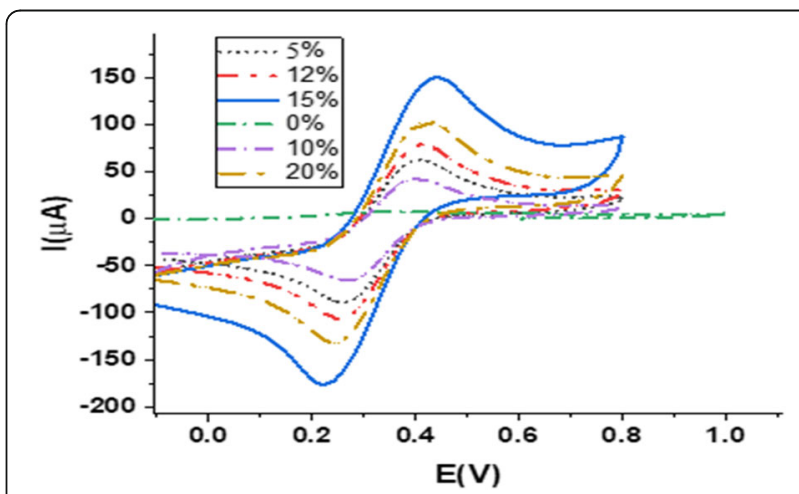

Fig. 3 Background-subtracted cyclic voltammograms at $50 \mathrm{mVs}^{-1}$ at bare $C P E$, and ratios of $\mathrm{Fe}_{2} \mathrm{O}_{3} \mathrm{NP} / \mathrm{CPES}$ in $1 \mathrm{mM}$ $\mathrm{K}_{4} \mathrm{Fe}(\mathrm{CN})_{6} / 0.1 \mathrm{M} \mathrm{KCl}$ solution 
were observed which slightly increased with increasing scan rate. This is common on carbon electrode surfaces (Yogeswaran and Chen 2007).

\section{Parameters optimization}

Effect of $\mathrm{pH}$ : The effect of solution $\mathrm{pH}$ on the electrochemical response of $\mathrm{LG}$ at $\mathrm{CPE} / \mathrm{Fe}_{2} \mathrm{O}_{3} \mathrm{NPs}$ was recorded in $\mathrm{B}-\mathrm{R}$ buffers and was found to be discerning over the $\mathrm{pH}$ range of $2-11$. The peak potentials decrease gradually in solutions as $\mathrm{pH}$ is raised, manifesting that protons have taken part in the electrode reaction processes. The results show that $\mathrm{pH} 7$ and 9 gave the maximum anodic peak current response, because the surface of iron oxide atoms act as Lewis acids and coordinate with water, which dissociates giving amphoteric hydroxyl group. These hydroxyl groups carry negative charges (Lefebure et al. 1998). And since the pKa value of LG is 9.86, therefore, an electrostatic attraction force was induced between the positively charged LG at alkaline
$\mathrm{pH}$ values and the negatively charged iron oxide nanoparticles surface which give a high current response. So, the rest of the work will be performed at $\mathrm{pH}$ 7.4 (physiological $\mathrm{pH}$ of the body).

Effect of varying the scan rate: The effect of varying the scan rate over the range of $10-240 \mathrm{mV} / \mathrm{s}$ was considered to detect the diffusion and adsorption characters of 1.0 LG at $\mathrm{CPE} / \mathrm{Fe}_{2} \mathrm{O}_{3} \mathrm{NP}$ surface in $\mathrm{B}-\mathrm{R}$ buffer $\mathrm{pH} 7.4$ using cyclic voltammetry (Fig. 4). The positive shift in the peak potential commends that the oxidation process is irreversible. The relation between the peak current versus square root of scan rate was constructed (inset A) giving a straight line with an equation of $I_{\mathrm{p}}(\mu \mathrm{A})=$ $1.08 \sqrt{ } v-0.153 ; R=0.9994$, which indicates mass transfer-controlling process of oxidation via diffusion. Also, a plot of log peak current with $\log$ scan rate gives a linear relationship with a slope of 0.494 (inset B), suggesting that $\mathrm{LG}$ oxidation on $\mathrm{CPE} / \mathrm{Fe}_{2} \mathrm{O}_{3} \mathrm{NPs}$ is mainly controlled by diffusion with some adsorption support.

The surface areas of $\mathrm{CPE}$ and $\mathrm{CPE} / \mathrm{Fe}_{2} \mathrm{O}_{3} \mathrm{NPs}$ were calculated using $1.0 \mathrm{mM} \mathrm{K}_{3} \mathrm{Fe}(\mathrm{CN})_{6}$ when $n=1$ and

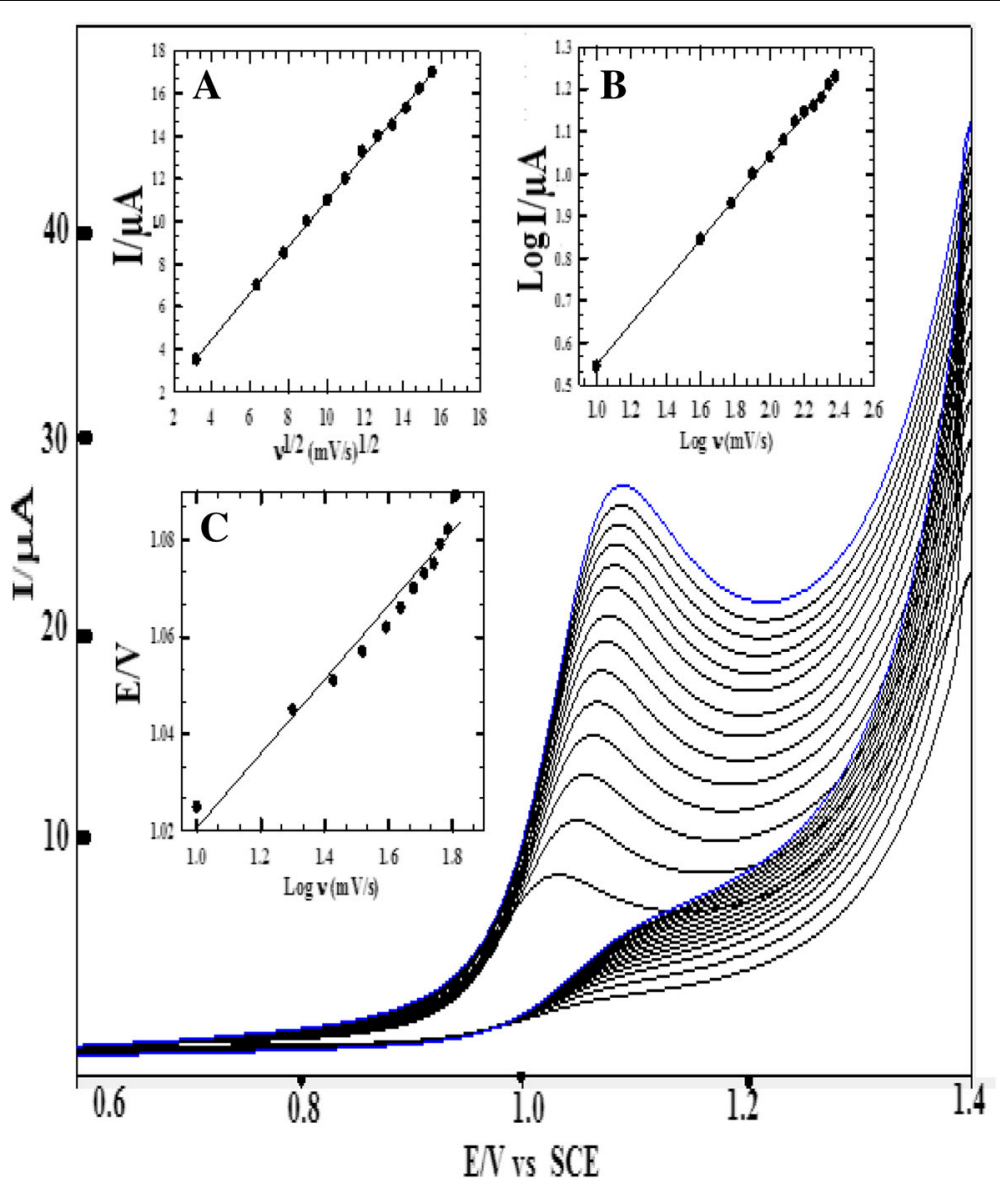

Fig. 4 Effect of varying the scan rate on $1.0 \mathrm{mM} \mathrm{LG}$ at $\mathrm{CPE} / \mathrm{Fe}_{2} \mathrm{O}_{3} \mathrm{NPs}$ in $\mathrm{B}-\mathrm{R}$ buffer $\mathrm{pH} 7.4$ using cyclic voltammetry. Inset a: Plot peak current versus square root of scan rate. Inset b: Plot of log peak current versus log the scan rate. Inset c: Plot of peak potential versus log the scan rate 
$D=7.6 \times 10^{-6} \mathrm{~cm}^{2} / \mathrm{s}$ using the Randles-Sevcik equation (Compton and Banks 2007; El-Shal et al. 2019)

$$
I_{\mathrm{p}}=2.69 \times 10^{5} n^{3 / 2} \mathrm{AD}^{1 / 2} v^{1 / 2} C
$$

The surface areas were evaluated to be $0.072 \mathrm{~cm}^{2}$ and 0.143, for CPE and $\mathrm{CPE} / \mathrm{Fe}_{2} \mathrm{O}_{3} \mathrm{NPs}$, respectively, which indicates that the addition of iron oxide nanoparticles doubled the surface area of the sensor and therefore increases the electroactive sites that enhanced the current response of LG.

Also, the determination of the sensor dynamics parameters $(\alpha$ and $n)$ is essential to determine the proposed mechanism of LG, Scheme 1. The relationship between Epa and $\log v$ (inset $C$ ) is given by the Laviron equation (Shen et al. 2009):

$$
\begin{aligned}
E_{\mathrm{p}}= & E_{0}+[2.303 \mathrm{RT} /(\alpha n \mathrm{~F})] \log \left[\left(\mathrm{RT} k_{\mathrm{s}}\right) /(\alpha n \mathrm{~F})\right] \\
& +[2.303 \mathrm{RT} /(\alpha n \mathrm{~F})] \log v
\end{aligned}
$$

where $\alpha$ is the electron transfer coefficient, $k_{\mathrm{s}}$ is the standard rate constant of the surface reaction, and $E_{0}$ is the formal potential obtained from the relation between $E_{\mathrm{p}}$ and $v$ by extrapolating to the vertical axis at $v=0$ and it was found to be $1.04 \mathrm{~V}, \alpha n$ can be calculated from the slope of $E_{\mathrm{p}}$ vs. $\log v$ (inset C). In this system, the slope is 0.0763, $\alpha n$ was calculated to be 0.777. From the Bard and Faulkner equation (Bard et al. 1980) and the CV plot of LG.

$$
\propto=\frac{47.7}{E_{p}-E_{p} / 2} m V
$$

The electron transfer coefficient was found to be 0.53 , and then, $n$ was calculated to be $1.2 \approx 1$ which indicated that only one electron was involved in the oxidation of LG. The value of $k_{\mathrm{s}}$ can be calculated from the intercept of the Laviron equation and was found to be $1.06 \times 10^{2} \mathrm{~s}^{-1}$.

\section{Discussion}

The electrooxidation performance of LG was documented as CV, in the range of 800 to $1300 \mathrm{mV}$ (Fig. 5), in B-R buffer $\mathrm{pH} 7.4$, at a scan rate of $100 \mathrm{mV} \mathrm{s}^{-1}$ for the tested electrodes: (bare $\mathrm{CPE})$ and $\left(\mathrm{CPE} / \mathrm{Fe}_{2} \mathrm{O}_{3} \mathrm{NPs}\right.$ ). For bare CPE, the anodic peak oxidation of LG appeared at $E_{\mathrm{p}}=1050 \mathrm{mV}$ with a current value of $2.5 \mu \mathrm{A}$. The peak current increases upon adding $\mathrm{Fe}_{2} \mathrm{O}_{3} \mathrm{NPs}$; this designated that the Fe2O3NPs has increased the sensor surface area. Finally, for $15 \%$ modified $\mathrm{CPE} / \mathrm{Fe}_{2} \mathrm{O}_{3} \mathrm{NPs}$, the anodic peak current extended to a highest value of $6.9 \mu \mathrm{A}$. This may be attributed to an electrostatic attraction among the cationic LG and the anionic $\mathrm{Fe}_{2} \mathrm{O}_{3} \mathrm{NPs}$ forming hydrogen bond that endorses faster electron transfer developing well the diffusion of LG among the surface. The schematic demonstration for this contact is explained in Fig. 5 inset.

Square wave voltammograms of LG with different concentrations from 0.03 to $86.2 \mu \mathrm{g} / \mathrm{ml}$ using CPE/ $\mathrm{Fe}_{2} \mathrm{O}_{3} \mathrm{NPs}$ were presented in Fig. 6. The International Conference on Harmonization (ICH) guidelines (I. H. T. (Guideline 1997)) for method validation were followed for validation of the suggested method. The current response increases steadily as a function of LG concentration, giving a calibration curve with a correlation coefficient of 0.9993 (inset A). Also, the detection limit $\mathrm{LOD}=3 \mathrm{~s} / \mathrm{m}$ and the quantification limit $\mathrm{LOQ}=10 \mathrm{~s} / \mathrm{m}$ were calculated, where $s$ is the standard deviation and $m$ is the slope of the calibration curves which were found to be $0.008 \mu \mathrm{g} / \mathrm{ml}$ and $0.026 \mu \mathrm{g} / \mathrm{ml}$, respectively.

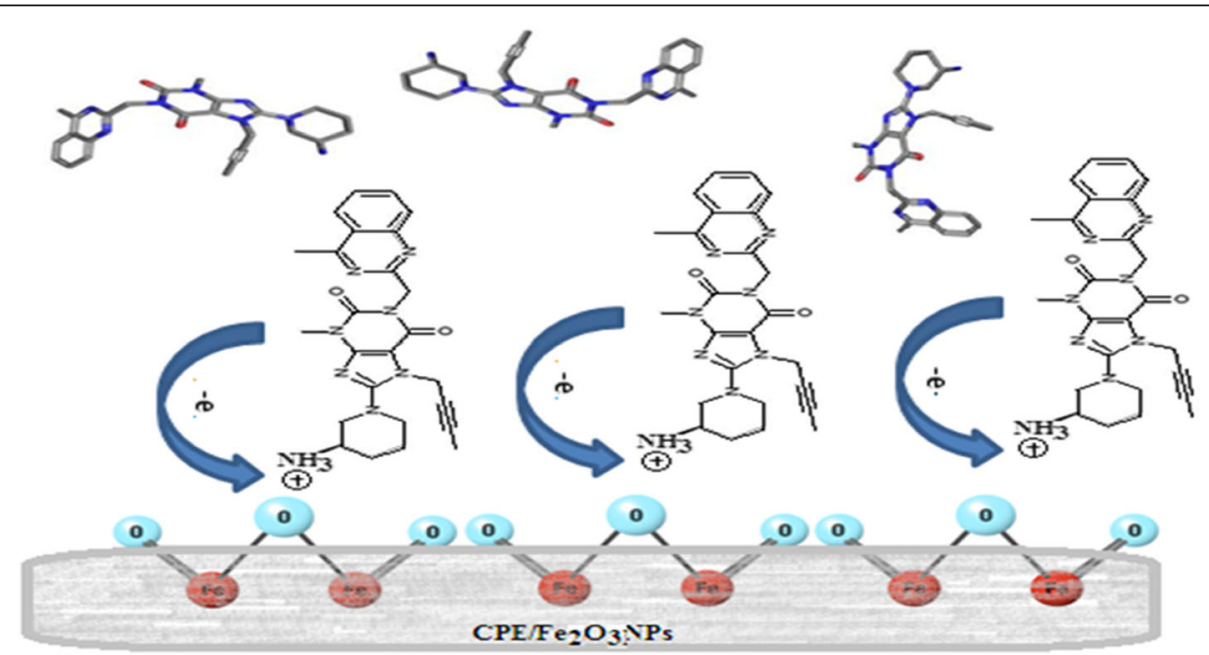

Scheme 1 The suggested mechanism for LG at CPE/Fe2O3NPs 


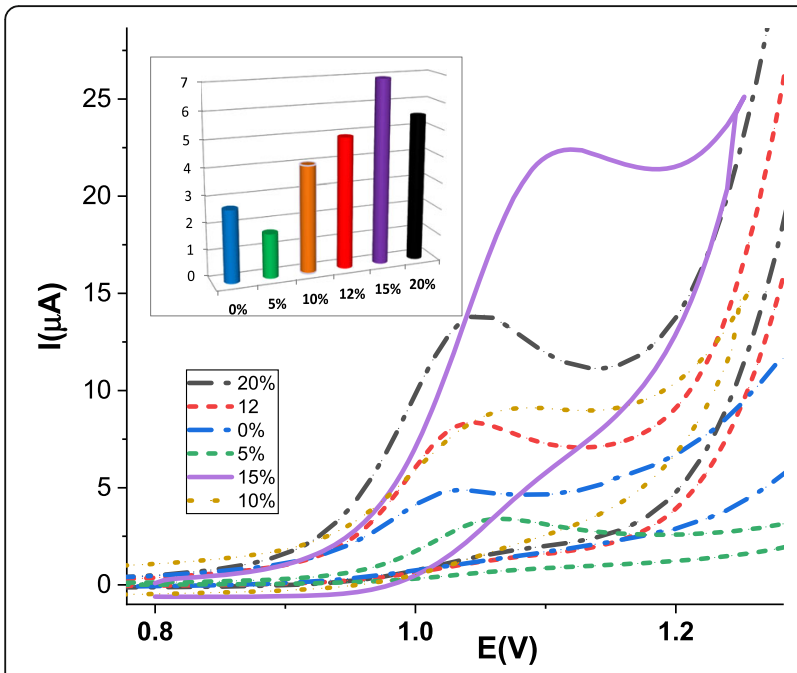

Fig. $5 \mathrm{CV}^{\prime} \mathrm{s}$ of $1.0 \times 10^{-5} \mathrm{~mol} \mathrm{~L} \mathrm{~L}^{-1}$ of LG in BR buffer $\mathrm{pH} 7.4$ at a scan rate of $100 \mathrm{mV} \mathrm{s}^{-1}$ by different modifier ratios electrodes

The high sensitivity of film can be attributed to the increase of the surface area with the iron oxide nanoparticles, the diffusion and adsorption mechanisms, high catalytic activity, and biocompatibility of the iron oxide NPs. The evaluated sensitivity of the fabricated CPE/ $\mathrm{Fe}_{2} \mathrm{O}_{3} \mathrm{NP}$ sensor is relatively higher than that of previously reported techniques (Table 1 ).

This is because the oxidation of $\mathrm{Fe}_{2} \mathrm{O}_{3} \mathrm{NPs}$ in aqueous media, in accordance with the dissolved oxygen $\left(\mathrm{O}_{2}\right)$ surrounding the electrode surface, leads to an increase in the adsorbed oxygen on the $\mathrm{Fe}_{2} \mathrm{O}_{3} \mathrm{NP}$ surfaces, which therefore increases oxidizing capability of the analyte. According to the following mechanisms (Banik et al.

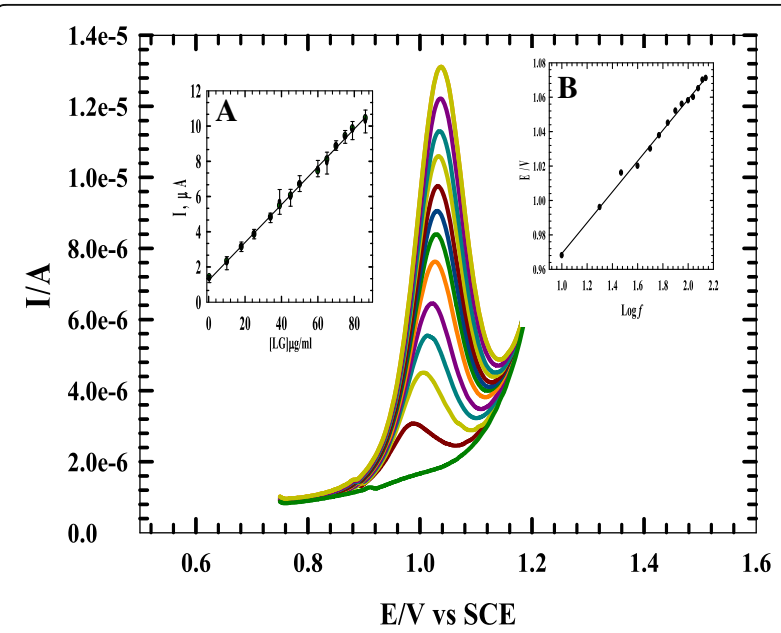

Fig. $6 \mathrm{SW}$ of the successive additions of $L G$ in $B-R$ buffer and 10 $\mathrm{mV} / \mathrm{s}$. Inset $\mathbf{a}$ : The calibration curve of $\mathrm{LG}$ at $\mathrm{CPE} / \mathrm{Fe}_{2} \mathrm{O}_{3} \mathrm{NPs}$. Inset b: The dependence of $E_{p}$ with $\log f$ for LG using Eq. (6)
2015; El-Bagary et al. 2013; Padmaja and Veerabhadram 2015; Bailey and Turner 1996:

$$
\begin{aligned}
& \mathrm{Fe}_{2} \mathrm{O}_{3} \mathrm{NPs}+\mathrm{O}_{2} \rightarrow \mathrm{O}_{2}^{-} \\
& \mathrm{Fe}_{2} \mathrm{O}_{3} \mathrm{NPs}+\mathrm{O}_{2}^{-} \rightarrow 2 \mathrm{O}^{-}
\end{aligned}
$$

Also, the reduced LG donates electrons to $\mathrm{Fe}_{2} \mathrm{O}_{3} \mathrm{NP}$ surface. Therefore, resistance is decreased, or conductance is increased.

\section{Influence of the square wave frequency (f)}

The square wave frequency determines the intensity of the signal and the sensitivity of the technique. The relation between the anodic current and the square wave frequency shows a linear relation up to $140 \mathrm{~s}^{-1}$ (Fig. 6, inset B). For larger values of frequency, the effect is almost negligible (O'Dea et al. 1993). This behavior corresponds to a totally irreversible process controlled by adsorption of the analyte on the electrode surface. Also, the peak potential should vary linearly with the logarithm of the frequency following the relationship:

$$
\frac{\Delta E_{P}}{\Delta \log f}=\frac{2.3 R T}{\alpha_{\mathrm{nF}}}
$$

A value of 0.66 was determined for $\alpha n$, and as the electron transfer coefficient was found to be 0.53 , therefore, $n=1.2$, indicating the transference of 1 electron per LG molecule, confirming the data obtained in the scan rate section. Thus, the suggested mechanism for LG is presented in Scheme 1.

\section{Specificity test}

Specificity of the method is monitored by measuring the current response of an analyte in the presence of other interferences. Glucose sensors account for approximately $85 \%$ of the biosensor industry. Non-enzymatic glucose electrodes give higher oxidation current response, higher stability, lower cost, and greater sensitivity. Electrocatalytic processes are important for glucose oxidation, since it is a kinetically very slow process with negligible faradaic current, showing a non-diffusion-controlled process (Vassilyev et al. 1985). The electrocatalysis occurs via the adsorption of analyte on the electrode surface, which involves the d-electrons to form bonds with the analyte (Pletcher 1984).

In this work, the specificity was checked by analyzing LG with MET and glucose in laboratory-prepared mixtures using bare CPE and $\mathrm{CPE} / \mathrm{Fe}_{2} \mathrm{O}_{3} \mathrm{NPs}$ in Fig. 7. No peak was observed for glucose in case of bare CPE, and only a broad peak was observed for MET and LG, while $\mathrm{CPE} / \mathrm{Fe}_{2} \mathrm{O}_{3} \mathrm{NP}$ sensor exhibits three good resolution anodic peaks: the first was for glucose which was oxidized to form glucolactone, which hydrolyses in $\mathrm{H}_{2} \mathrm{O}$ to form 
Table 1 Comparison of the proposed method with other methods

\begin{tabular}{|c|c|c|c|c|c|}
\hline Method & Linear range $(\mu \mathrm{g} / \mathrm{ml})$ & Solvent & $\mathrm{LOD}(\mu \mathrm{g} / \mathrm{ml})$ & Recovery & Reference \\
\hline Spectrophotometric & $8-32$ & $\mathrm{H}_{2} \mathrm{O}$ & 0.247 & $100.39 \%$ & (Shehata et al. 2016) \\
\hline HPLC & $0.125-4$ & Methanol & 0.03 & $11.07 \%$ & (Shen et al. 2009) \\
\hline Spectrophotometric & $2-12$ & Methanol & & $99.86 \%$ & (Vassilyev et al. 1985) \\
\hline RP-HPLC & $10-50$ & Methanol and phosphate buffer & 1.65 & $99.79 \%$ & (Vemula et al. 2015) \\
\hline $\mathrm{CPE} / \mathrm{Fe}_{2} \mathrm{O}_{3} \mathrm{NPS}$ & $0.03-86$ & Universal buffer & 0.008 & $100.1 \%$ & Proposed method \\
\hline
\end{tabular}

gluconic acid giving an anodic peak current at $260 \mathrm{mV}$, and the second peak at 760 is due to the oxidation of the imino group in guanidino group to a N-hydroxy imino group of metformin (Jerez et al. 2014), while the third one is due to LG oxidation at $960 \mathrm{mV}$. Also, linagliptin's recovery was examined with some related substances that potentially present with LG in the dosage formulation under optimum conditions when the concentration of each constituent was $1.0 \times 10^{-3} \mathrm{M}$ and was found to be 99.66, 98.10, 99.93, 99.60, and 98.92 for glucose, metformin, talc, urea, and starch, respectively.

These results indicate that these substances did not interfere with LG, which confirms the specificity of the proposed method, since the tolerance limit was less than $2 \%$.

\section{Application of linagliptin}

In pharmaceutical formulation: For the purpose of the practical applicability of the proposed method and the modified sensor, the SWV method was applied for the investigation of LG in five Trajenta ( $5 \mathrm{mg} /$ tablet) tablets without any sample extraction to obtain $1.0 \mathrm{mM}$ LG solution. The validity of the proposed method was evaluated by the standard addition technique, and the accuracy has

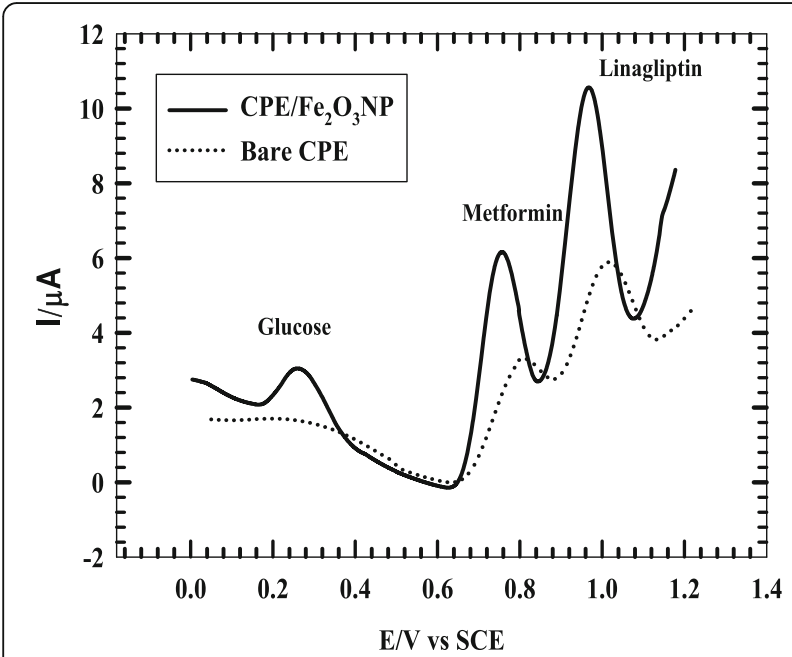

Fig. 7 SW of B-R buffer solution ( $\mathrm{pH}$ 7.4) containing LG with MET and glucose monitored at bare CPE and $\mathrm{CPE} / \mathrm{Fe}_{2} \mathrm{O}_{3} \mathrm{NPS}$ been determined giving satisfactory recoveries from 99.98 to $101.9 \%$, and relative standard deviation from 0.04 to $0.63 \%$ reveals that the excipient presented in the tablet does not interfere with the active ingredient. The results suggested that $\mathrm{CPE} / \mathrm{Fe}_{2} \mathrm{O}_{3} \mathrm{NPs}$ has high reproducibility and would be useful sensor for quantitative analysis of LG in pharmaceutical formulations.

In spiked urine sample: The validation of $\mathrm{CPE} / \mathrm{Fe}_{2} \mathrm{O}_{3} \mathrm{NPs}$ for the quantitative assay of LG in urine was examined in B-R buffer pH 7.4. Six different concentrations on the calibration curve are chosen to be repeated for five times to evaluate the accuracy and precision of the proposed method, which shows a recovery values from 99.9-100.1\%. Also, the statistical analysis of the results was obtained by applying the proposed and the reported methods, and the mean \pm S.D. of LG in urine sample was found to be $100.05 \pm 0.25$ for the proposed method with $t$ (2.776) value of 0.575 and $F(19)$ value of $3.760(n=4)$, while the mean \pm S.D. for the reported method was found to be $99.95 \pm 0.13$ when the values between parentheses was $85 \%$.

\section{Conclusion}

This work describes a new and very simple CPE sensor for the electrochemical determination of linagliptin in pharmaceutical formulations, in urine samples, and in the presence of glucose and the co-administered drug MET using magnetic iron oxide nanoparticles. Some dynamic parameters are considered for the first time. The results showed that the method was sensitive, precise, and selective with no significant effects of the excipients background. A linear relation between LG peak current and its concentration in the range 0.03 to $86 \mu \mathrm{g} / \mathrm{ml}$ leads to a detection limit of $0.008 \mu \mathrm{g} / \mathrm{ml}$.

Acknowledgements

The authors acknowledge with thanks NODCAR for the technical support.

Funding

This work has no funds.

Availability of data and materials

All data generated or analyzed during this study are included in this published article. 


\section{Authors' contributions}

All authors contributed in this work and in writing the manuscript. All authors read and approved the final manuscript.

\section{Ethics approval and consent to participate}

The manuscript does not contain studies involving human participation.

\section{Consent for publication}

Not applicable.

\section{Competing interests}

The authors declare that they have no competing interests.

\section{Publisher's Note}

Springer Nature remains neutral with regard to jurisdictional claims in published maps and institutional affiliations.

Received: 29 January 2019 Accepted: 15 May 2019

Published online: 13 June 2019

\section{References}

Abbas Moussa B, Mahrouse MA, Fawzy MG (2019) A validated LC-MS/MS method for simultaneous determination of linagliptin and metformin in spiked human plasma coupled with solid phase extraction: application to a pharmacokinetic study in healthy volunteers. J Pharm Biomed Anal 30(163):153-161

Association AD (2014) Standards of medical care in diabetes. Diabetes Care 37:S14-S80

Azab SM, Fekry AM (2017a) A novel electrochemical determination for the antiosteoporosis drug (alendronate sodium) and its application for corrosion monitoring of surgical 316 L SS bone implant. J Alloy Compd 717:25-30

Azab SM, Fekry AM (2017b) Electrochemical design of a new nanosensor based on cobalt nanoparticles, chitosan and MWCNT for the determination of daclatasvir: a hepatitis $C$ antiviral drug. RSC Adv 7:1118-1126

Baby TT, Ramaprabhu S (2010) SiO2 coated Fe3O4 magnetic nanoparticle dispersed multiwalled carbon nanotubes based amperometric glucose biosensor. Talanta 80:2016-2022

Bailey CJ, Turner RC (1996) Metformin. N Eng L J Med 1996(334):574-579

Banik S, Karmakar P, Miah MAH (2015) Development and validation of a UVspectrophotometric method for determination of vildagliptin and linagliptin in bulk and pharmaceutical dosage forms. Bangladesh Pharm J 18:163-168

Bard AJ, Faulkner LR, Leddy J, Zoski CG (1980) Electrochemical methods: fundamentals and applicationsEditor. Wiley, New York, p 2

Brocks D, Gabr RQ, Padwal RS (2010) Determination of metformin in human plasma and urine by high-performance liquid chromatography using small sample volume and conventional octadecyl silane column. J Pharm Pharm Sci 13:486-494

Compton R G, Banks C E (2007) Understanding Voltammetry, World Scientific

El-Bagary RI, Elkady EF, Ayoub BM (2013) Spectrophotometric methods for the determination of linagliptin in binary mixture with metformin hydrochloride and simultaneous determination of linagliptin and metformin hydrochloride using high performance liquid chromatography. Int J Biomed Sci 9:41

El-Shal MA, Hendawy HAMH, Eldin GMG, El-Shiref ZA (2019) Application of nano graphene modified electrode as an electrochemical sensor for determination of tapentadol in presence of paracetamol. J Iran Chem Soc. https://doi.org/ 10.1007/s13738-018-01585-z

Group UPDS (1998) Intensive blood-glucose control with sulphonylureas or insulin compared with conventional treatment and risk of complications in patients with type 2 diabetes (UKPDS 33). Lancet 352:837-853

IHT Guideline (1997) Fed Regist:62

Haak T (2015) Combination of linagliptin and metformin for the treatment of patients with type 2 diabetes. Clin Med Insights Endocrinol Diabetes 8:1

Jalilian A, Panahifar A, Mahmoudi M, Akhlaghi M, Simchi A (2009) Preparation and biological evaluation of [ $67 \mathrm{Ga}$-labeled-superparamagnetic nanoparticles in normal rats. Radiochim Acta 97:51-56

Jerez LB, García-Pérez U, Zambrano-Robledo P, Hernández-Moreira J (2014) Carbon paste electrode modified with BiVO4 to sense metformin. Int J Electrochem Sci 9:4643-4652

Laurent S, Dutz S, Häfeli UO, Mahmoudi M (2011) Magnetic fluid hyperthermia: focus on superparamagnetic iron oxide nanoparticles. Adv Colloid Interfac $166: 8-23$
Lefebure S, Dubois E, Cabuil V, Neveu S, Massart R (1998) Monodisperse magnetic nanoparticles: preparation and dispersion in water and oils. J Mater Res 13:2975-2981

Li J, Yuan R, Chai Y, Che X (2010) Fabrication of a novel glucose biosensor based on Pt nanoparticles decorated iron oxide-multiwall carbon nanotubes magnetic composite. J Mol Catal B Enzym 66:8-14

Mohamed MA, Fekry AM, El-Shal MA, Banks CE (2017) Incorporation of tetrazolium blue (TB)/gold nanoparticles (GNPs) into carbon paste electrode: application as an electrochemical sensor for the sensitive and selective determination of sotalol in micellar medium. Electroanalysis 29:2551

O'Dea JJ, Ribes A, Osteryoung JG (1993) Characterization of quasi-reversible surface processes by square-wave voltammetry. J Electroanal Chem y 345:287-301

Padmaja N, Veerabhadram G (2015) Development and validation of analytical method forsimultaneous estimation of empagliflozin and linaglptin in bulk drugs and combined dosage forms using UV-visiblespectroscopy. Pharm Lett 7:306-312

Pletcher D (1984) Electrocatalysis: present and future. J Appl Electrochem 14:403-415

Polyak B, Friedman G (2009) Magnetic targeting for site-specific drug delivery: applications and clinical potential. Expert Opin Drug Del 6:53-70

Prodan AM, Iconaru SL, Chifiriuc CM, Bleotu C, Ciobanu CS, Motelica-Heino M, Sizaret S, Predoi D (2013) Magnetic properties and biological activity evaluation of iron oxide nanoparticles. J Nanomater 2013:7

Rong LQ, Yang C, Qian QY, Xia XH (2007) Study of the nonenzymatic glucose sensor based on highly dispersed Pt nanoparticles supported on carbon nanotubes. Talanta 72:819-824

Salimi A, Sharifi E, Noorbakhsh A, Soltanian S (2007) Immobilization of glucose oxidase on electrodeposited nickel oxide nanoparticles: direct electron transfer and electrocatalytic activity. Biosens Bioelectron 22:3146-3153

Shehata M, Azab S, Fekry A, Ameer M (2016) Nano-TiO 2 modified carbon paste sensor for electrochemical nicotine detection using anionic surfactant. Biosens Bioelectron 79:589-592

Shen Y, Tang J, Nie Z, Wang Y, Ren Y, Zuo L (2009) Preparation and application of magnetic $\mathrm{Fe} 3 \mathrm{O} 4$ nanoparticles for waste waterpurification. Sep Purif Technol 68:312-319

Vassilyev YB, Khazova O, Nikolaeva N (1985) Kinetics and mechanism of glucose eiectrooxidation on different electrode-catalysis. J Electroanal Chem Interfacial Electrochem 196:105-125

Vemula P, Dodda D, Balekari U, Panga S, Veeresham C (2015) Simultaneous determination of linagliptin and metformin by reverse phase-high performance liquid chromatography method: an application in quantitative analysis of pharmaceutical dosage forms. J Adv Pharm Technol Res 6(1):2528

WaldhäusI W, Kleinberger G, Korn A, Dudczak R, Bratusch-Marrain P, Nowotny P (1979) Severe hyperglycemia: effects of rehydration on endocrine derangements and blood glucose concentration. Diabetes 28:577-584

Yogeswaran U, Chen SM (2007) Separation and concentration effect of fMWCNTs on electrocatalytic responses of ascorbic acid, dopamine and uric acid at f-MWCNTs incorporated with poly (neutral red) composite films. Electrochim Acta 52(19):5985-5996

\section{Submit your manuscript to a SpringerOpen ${ }^{\circ}$ journal and benefit from:}

- Convenient online submission

- Rigorous peer review

- Open access: articles freely available online

High visibility within the field

- Retaining the copyright to your article

Submit your next manuscript at $\boldsymbol{\nabla}$ springeropen.com 